\title{
KOMPETENSI DAN KEMAMPUAN BAHASA INGGRIS HUMAS PEMDA DKI UNTUK MENINGKATKAN LAYANAN PUBLIK
}

\author{
Drs. Faisal Slamet Riyadi. MM. \& Dra. Mawarta Onida S, M.Si. \\ Asri Desiani dan Sita Utami \\ Jurusan Administrasi Niaga Politeknik Negeri Jakarta Kampus UI Depok
}

\begin{abstract}
This research is entitled the competency and communication of public relation officer local distric government of Jakarta in order to to create various competency or ability to do public speaking activies like: delivery speech, making presentation, do negotiation and being as master of ceremony on official event as well as ceremony. This research is aimed to make the staff og public realtion officer not only able to the public to see their capability to speak english and how their ability to write article in english. It is very important as the government officer that give the service excellent to the public. This field research is done directly in the office of government. The result show that the public relation officer are able to speak english and write english article published on printed media. The are able ti do it because they are helped by the professional consultant to arrange, to compose the draft and the concept of writing article. We can see the sample of the article written by public relation officer on printed media like we put on enclosure.
\end{abstract}

Key word : competency, MICE study program, negotiating, presentation, delivery speech, master of ceremony and competency.

\section{PENDAHULUAN}

\section{Latar Belakang}

Pemerintah diadakan untuk melayani masyarakat, serta mencipkakan suatu kondisi yang memungkinkan anggota masyarakat mengembangkan kemampuan dan kreativitasnya demi mencapai tujuan bersama. Badan atau instansi pemerintah yang ada diharapkan dapat memberikan pelayanan dan informasi yang sesuai dengan tugas dan bidangnya masing-masing, karean sesuai dengan prinsip kerja instansi pemerintah bahwa mereka harus menjadi pelayan masyarakat dan pengembangan organisasi.

Komunikasi yang terarah dan terstruktur dapat menciptakan statement yang baik dan otomatis menimbulkan persepsi yang baik sehingga timbul image atau citra yang baik sebaliknya penyampaian komunikasi yang baik juga mempengaruhi image atau citra lembaga teresbut. Public Relation Officer sebagai sentral gerbang informasi dalam suatu kantor memegang peranan yang sangat sentral dimanan ia adalah suatu unit yang mengelola dan mendistribusikan informasi baik untuk kalangan intern maupun ekstern oleh karena itu dibutuhkan kemampuan memahami informasi yang melalui kemampuan berkomunikasi dalam bahasa nasional dan internasional. Mengingat pentingnya posisi, tugas dan fungsi Public Relation tentu dituntut suatu ketrampilan dalam berkomunikasi khususnya dakam bahasa asing. Tuntutan kemampuan berkomunikasi dalam bahasa inggris tumbuh dan berkembang seiring dengan berkembangnya informasi, ilmu pengetahuan dan teknologi yang sangat cepat yang 
telah merambah dalam segala aspek kehidupan. Ketrampilan berkomunikasi dalam bahasa Inggris dituntut dari seorang Public Relation, hal ini sejalan juga dengan gerakan otonomi daerah yang dicanangkan dalam Undang-Undang No.22 dan 25 Tahun 1999 tentang Otonomi Daerah yang secara langsung berpengaruh terhadap perencanaan, pelaksanaan dan evaluasi masing-masing instansi. Otonomi daerah memberi keleluasaan pemerintah daerah setempat untuk mengelola potensi dan asset daerah. Pengelolaan potensi dan aset daerah harus melibatkan manusia atau SDM sebagai tenaga sentral yang merancang, mengoperasionalkan potensi tersebut. Sejak dilansirnya hilangnya sentralisasi yang menuju otonomi daerah banyak pihak yang meragukan otonomi daerah sulit dilaksanakan berhubung terbatasnya dan rendahnya kualitas SDM pada setiap instansi pemerintah.. Dengan adanya kebebasan dalam pengelolaan aset dan potensi daerah pasti terbuka kesempatan dan peluang untuk menjalin kerjasama dengan pihak swasta lokal, asing dan investor, oleh karena itu penguasaan dan kemapuan berbahasa Inggris sebagai media komunikasi bagi seorang PR sangat diperlukan. Seiring dengan dicanangkannya tahun pelayanan publik pada tahun 2006 oleh instansi pemerintah, hal ini berarti betapa pentingnya pelayanan public diberikan kepada masyarakat.

\section{Perumusan Masalah}

Perumusan Masalah dalam penelitian ini adalah:

- Apa saja tugas, jenis kegiatan, peranan Public Relation Officer (Humas) pemda DKI dalam membangun informasi bagi publik internal dan eksernal?

- Bagaiman kompetensi Publi cRelation Officer beserta staf pendukung dalam menjalankan tugasnya?

- Bagaimana kemampuan berbahasa inggris Publi Relation Officer tsb beserta staf pendukung lainnya

- Masalah-masalah apa yang dihadapi serta solusi apa yang mereka lakukan terkait dengan kemampuan bahasa inggris mereka.

Konsep dan unsur kompetensi public relation officer yang akan diukur adalah :

1. Pengetahuan (knowledge) yaitu kesadaran dalam bidang kognitif dan mengetahui cara melakukan tugasnya.

2. Pemahaman (understanding), yaitu ketrampilan apa yang dimiliki seorang public relation officer dalam menjalankan tugasnya.

3. Nilai (value), yaitu standard perilaku yang telah diyakini dan telah menyatu dalam dirnya, misalnya standard perilaku seorang public relation officer adalah well informed bersifat terbuka. dan full hospility.

4. Minat (interest), yaitu kesadaran seseorang untuk melakukan pekerjaan yang didasari oleh inisiatif yang tinggi, sadar akan tugasnya secara proaktif

Sumber : Gordon, dalam bukunya :Konsep Karakteristik dan Implementasi. 2003

Kemampuan bahasa inggris public relation officer (humas) diuji dalam 2 skill, yaitu; speaking dan writing

Speaking test dilaksanakan dengan mengadakan interview dalam bahasa Inggris dengan mengambil 3 materi test utama yang berhubungan erat dengan tugas seorang PR, yaitu :

- Dealing with Visitor \& Customer

- Giving Reason 
- Expressing Opinion

- Giving presentation dan

- Product knowledge yaitu pemahaman 5W 1H (what, where, when, who, which and how)

Sementara writing test dilaksanakan dengan pengujian terhadap pemahaman konsep dasar penulisan surat (letter) dan pemahaman tentang Structure \& Presentation sebagai pemahaman dasar dalam menulis surat yang mencakup :

- Layout 1 (letter head, date, salutation, body of letter, complimentary closes)

- Layout 2 (subject title, enclosure, c.c. \& b.c.c)

- Layout 3 (per pro, company position)

Instrumen yang digunakan adalah lembar tes, daftar wawancara terstruktur, checklist dan observation sheet. Data yang didapatkan akan diolah dan diuraikan menjadi suatu informasi yang disajikan secara sistematis dan komprehensif dalam deskripsi dan justifikasi.

DIvisi yang dituju dan yang diteliti adalah Divisi Humas dan Sub bagian Humas serta Protokoler, seperti yang tercantum pada gambar di bawah ini. Jumlah personil yang dijadikan sample berjumlah 15 orang dari bagian humas dan 15 orang dari sub bagian humas dan protokoler. 


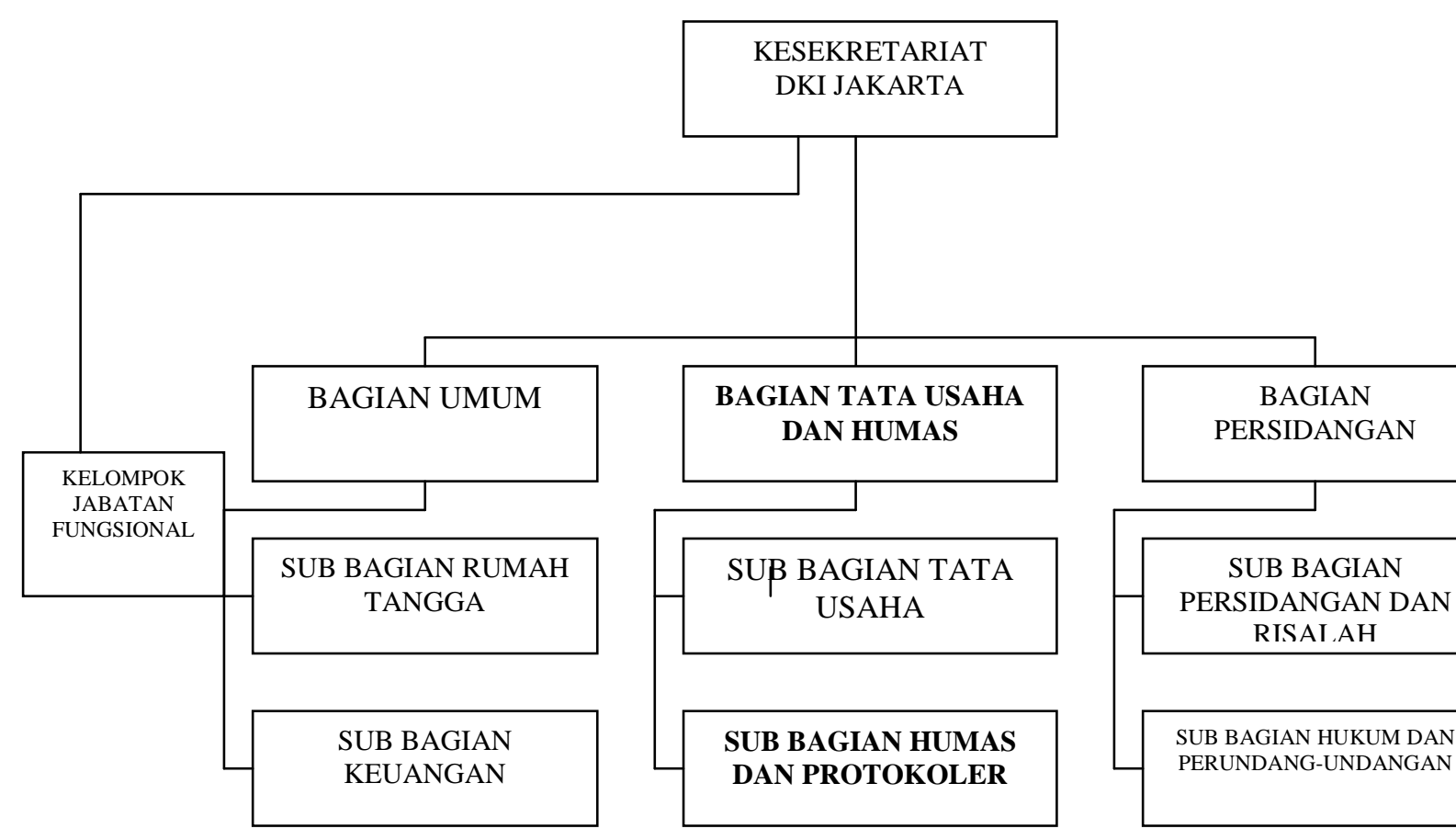

Sumber : Data diolah 2009

\section{TINJAUAN PUSTAKA}

Kompetensi merupakan kemampuan dan ketrampilan melakukan sesuatu yang dapat diukur (Simanjuntak Payaman. 2005: 10)

Beberapa aspek yang terkandung dalam kompetensi adalah:

1. Pengetahuan (knowledge) yaitu kesadaran dalam bidang kognitif dan mengetahui cara melakukan tugasnya.

2. Pemahaman (understanding), yaitu memahami tentang apa yang dilayani.

3. Kemampuan (skill), yaitu sesuatu yang dimiliki (keterampilan) apa yang dimiliki seorang PR untuk melakukan tugasnya.

4. Nilai (value), yaitu standard perilaku yang telah diyakini atau telah menyatu dalam dirinya, misaalnya: standard perilaku seorang petugas Humas adalah: well informed dan bersifat terbuka

5. Minat (interest), yaitu kecenderungan seseorang untuk melakukan sesuatu pekerjaan. (Gordon. 2003: 35)

Berdasarkan pemahaman kompetensi di atas, maka kata kunci kompe-tensi adalah kemampuan.

Pedoman umum penyelenggaraan pelayanan publik mengatakan bahwa : terwujudnya layanan public yang berkualitas merupakan salah satu ciri pemerintahanyang baik (good government). Disadari bahwa kebijakan pemberdayaan aparatur Negara khususnya dalam peningkatan pelayanan publik harus memperhatikan tuntutan dinamika masyarakat yang berubah dalam suasana eporia reformasi, demokratisasi, desentralisasi dan otonomi daerah dan penegakan HAM adalah termasuk pelayanan publik upaya terus menerus dan berkelanjutan.( Surat Keputusan Menpan No 63/kep 
63/M.PAN/2005 Diantara sekian banyak tugas Public Relation yaitu kegiatan yang berkenaan dengan penguasaan bahasa asing seperti press release, pengelolaan dinding informasi, surat kabar lokal maupun internasional, media elektronik RRI dan televisi swasta dimana bahasa Inggris baik lisan maupun tulisan (Buku Program Kerja Setda DKI, 2005:.35)

Teknik dan taktik komunikasi untuk promosi mangatakan ; dikalangan pemerintah Public Relations lebih dikenal dengan istilah HUMAS singkatan dari Hubungan Masyarakat harus mampu memberikan layanan publik yang bersifat offensife dan ekspansif yaitu meluaskan promosi dan mengembangkan informasi secara terpadu sehingga tercipta suasana komunikatif di masyarakat. Untuk memperoleh hal terbaik tersebut sudah sewajarnya paling tidak seorang Public Relation harus menguasai teknik dan taktik berkomunikasi yang efektif baik dalam bahasa Indonesia maupun bahasa Inggris.(Doche Rudolf. 1993: 78)

Commuication Your Messue To International Stakeholder/Guest mengatakan bahwa the role of Communications cover : Strategic Considration, Positioning, Messaging and Program Development and Measurement. Jeffrey juga mengatakan bahwa how to communicate effectively to different International is very urgent especially those ones concerned to Public Services. Disamping itu ditegaskan pula bahwa Institutions, they need to develop comprehensively communications program to support the organizations objective (Jeffrey Schulfz, prosiding seminar 2006\}

Scope Public Relations berkenaan dengan kemampuan berkomunikasi sebab mereka sering berurusan dengan :

- Media Relation

- Publication

- Investor Relation

- Change Communication

- Product Promotion in 5W+1H

Humas menduduki posisi yang sangat sentral dan vital sebab tugas-tugas mereka adalah berkewajiban meningkatkan komunikasi ke atas dan ke bawah, luar dan dalam. Komunikasi ke dalam meliputi : penyajian majalah karyawan, laporan berkala, papan informasi/bulletin, film, poster, surat tata tertib dan nota antar jawatan.

Komunikasi ke luar meliputi : Penanganan kotak saran/usul, surat complaint, dan meeting dengan instansi lain. Salah satu yang sangat urgent yang dihadapi humas adalah barang cetakan (printed matters) baik yang tertulis dalam bahasa Indonesia dan bahasa Inggris. Kemampuan berkomunikasi dalam bahasa Inggris juga harus dimiliki oleh seorang PR untuk mengantisipasi perkembangan di masa mendatang. (Weinsten Bob. 1002: 17)

Communication has become essential nowadays especially, during the globalization era not only for public relations and journalistic but also those people involved to the public services. Public relations is management function can communicate with all internal and external public in order to create the balance between the organization objective and the customer expectation. (Yuliana Eka. 2002: 7 \}

Saat ini kemampuan berbahasa di depan umum (Public Speaking) dalam bahasa Inggris sudah begitu penting dan mendesak terlebih lagi hubungan antar bangsa, era globalisasi dan otonomi daerah khususnya bagi mereka yang bertindak sebagai juru bicara pelayan masyarakat yang mewakili organisasi.(Mulyana Yayan G. 200: 3 \} 


\section{TUJUAN DAN MANFAAT PENELITIAN}

\section{Tujuan Penelitian}

Penelitian ini penting direncanakan sebab dengan dilaksanakannya penelitian ini akan berguna dan membantu dosen penelitu bersama mahasiswa bimbingannya untuk :

- Mengetahui tentang tugas, jenis kegiatn dan peranan para Public Relation Officer pemda DKI dalam menjalin komunikasi kepada masyarakat

- Mengetahui bagaimana kompetensi public relation officer pemda DKI dalam menjalankan tugas utamanya dalam memberikan layanan informasi kepada masyarakat

- Mengetahui bagaimana kemampuan berbahasa Inggris mereka khususnya dalam bidang speaking dan writing

- Mengetahui solusi yang mereka lakukan dalam memecahkan masalah yang ada terkait dengan kemampuan bahasa inggris

- Membantu mahasiswa bimbingan untuk lebih mengenal dunia penelitian dan tentu saja akan berdampak pada pemahaman terkait dengan pelaksanaan praktek kerja lapangan dan penulisan tugas akhir mereka.

\section{Luaran Yang Diharapkan}

Luaran yang diharapkan dari hasil penelitian ini adalah

- Penelitian ini diharapkan akan menghasilkan output atau luaran yaitu dirancangnya paket pelatihan bahasa inggris yang akan ditawarkan kepada pemda DKI untuk mengikutseertakan staf humas dan staf pendukung untuk mengikuti pelatihan bahasa inggris yang akan dilaksanakan oleh lembaga bahasa UP2B (Unit Penerapan dan Pengembangan Bahasa) Politeknik Negeri Jakarta. Peluang ini mempunyai prospek, sebab Lembaga Bahasa PNJ mempunyai aneka paket pelatihan yang dapat ditawarkan pada pemda dalam upaya pengembangan SDM

- Hasil penelitian ini diharapakan juga akan menghasilkan suatu paket pelatihan sebagai output yang dapat ditawarkan kepada pihak pemda DKI tentang pelayanan prima atau service excellent yang layak diberikan pada masyarakat internal dan external. Pelayanan prima atau service excellence menjadi sangat penting khususnya dalam pelaksanaan otonomi daerah dimana pemda berpeluang besar untuk memberikan informasi untuk mengundang partisipasi masyarakat dan juga pihak investor untuk menanamkan investasi di daerahnya masing-masing.

\section{Kegunaan Penelitian}

- Hasil penelitian ini bermanfaat bagi terjadinya peningkatan kualitas SDM dalam hal ini Public Relation Officers Instansi Pemerintah dimanapun diharapkan mampu memberikan pelayanan yang baik ( Good Public Services atau service excellent) melalui pelayanan yang baik dan bermutu sesuai dengan standar yang ditetapkan dalam surat Menpan No.36/KEP/M.PAN/2003

- Hasil penelitan ini diharapkan akan membawa dampak pada timbulnya kesadaran bagi personil humas pemda DKI untuk mau meningkatkan kemampuan bahasa inggris mereka

- Hasil penelitian ini kelak bermanfaat bagi dosen peneliti, untuk dapat menjadikan ini sebagai dasar mengajukan proposal pengadaan pelatihan tentang bidang komunikasi, hubungan masyarakat dan pelatihan bahasa inggris kepada pemda 
DKI guna menngkatkan kompetensi staf humas pemda DKI di masa yang akan datang.

\section{METODE PENELITIAN}

Metode penelitian yang digunakan dalam penelitian ini adalah metode kwalitatif yang menguraikan semua data yang diolah dalam bentuk keterangan dan penjelasan secara sistematis dan comprehensive. Adapun langkah-langkah yang ditempuh adalah sebagai berikut :

1. Melakukan observasi bersama 3 mahasiswa bimbingan ke kantor tempat mahasiswa melakukan job training dan mengambil data untuk penulisan tugas akhir. Hal ini bertujuan untuk mengadakan pencatatan, pengamatan dan pengambilan data tentang naskah, literature berbahasa Inggris (incoming, letter, \& literature) yang ada 2 tahun terakhir.

2. Mengadakan interview untuk mengetahui tugas, peranan dan masalah-masalah yang mereka hadapi.

3. Menyebarkan angket yang memuat ketiga variabel yaitu: variabel kompetensi (X1) dan variabel kemampuan bahasa inggris (X2) serta variabel pelayanan publik (Y).

4. Meneliti kompetensi para public relation officer instansi pemerintah tsb dengan meneliti dan mengamati kompetensi seorang humas, yaitu seperti tersebut di atas, yaitu; Knowledge, Understanding, Skill, Value dan Interest

5. Melakukan tes kemampuan bahasa Inggris dengan dua cara yaitu Speaking \& Writing.

Speaking test dilaksanakan dengan mengadakan interview dalam bahasa Inggris dengan mengambil 3 materi test utama yang berhubungan erat dengan tugas seorang PR, yaitu :

- Dealing with Visitor \& Customer

- Giving Reason

- Expressing Opinion

- Giving presentation dan

- Product knowledge yaitu pemahaman 5W 1H (what, where, when, who, which and how)

Sementara writing test dilaksanakan dengan pengujian terhadap pemahaman konsep dasar penulisan surat (letter) dan pemahaman tentang Structure \& Presentation sebagai pemahaman dasar dalam menulis surat yang mencakup :

- Layout 1 (letter head, date, salutation, body of letter, complimentary closes)

- Layout 2 (subject title, enclosure, c.c. \& b.c.c)

- Layout 3 (per pro, company position)

Instrumen yang digunakan adalah lembar tes, daftar wawancara terstruktur, checklist dan observation sheet. Data yang didapatkan akan diolah dan diuraikan menjadi suatu informasi yang disajikan secara sistematis dan komprehensif dalam deskripsi dan justifikasi. 
Speaking test dilaksanakan dengan mengadakan interview dalam bahasa Inggris dengan mengambil 3 materi test utama yang berhubungan erat dengan tugas seorang PR, yaitu :

- Dealing with Visitor \& Customer

- Giving Reason

- Expressing Opinion

- Giving presentation dan

- Product knowledge yaitu pemahaman 5W 1H (what, where, when, who, which and how)

Sementara writing test dilaksanakan dengan pengujian terhadap pemahaman konsep dasar penulisan surat (letter) dan pemahaman tentang Structure \& Presentation sebagai pemahaman dasar dalam menulis surat yang mencakup :

- Layout 1 (letter head, date, salutation, body of letter, complimentary closes)

- Layout 2 (subject title, enclosure, c.c. \& b.c.c)

- Layout 3 (per pro, company position)

Instrumen yang digunakan adalah lembar tes, daftar wawancara terstruktur, checklist dan observation sheet. Data yang didapatkan akan diolah dan diuraikan menjadi suatu informasi yang disajikan secara sistematis dan komprehensif dalam deskripsi dan justifikasi.

Kerangka Pemikiran

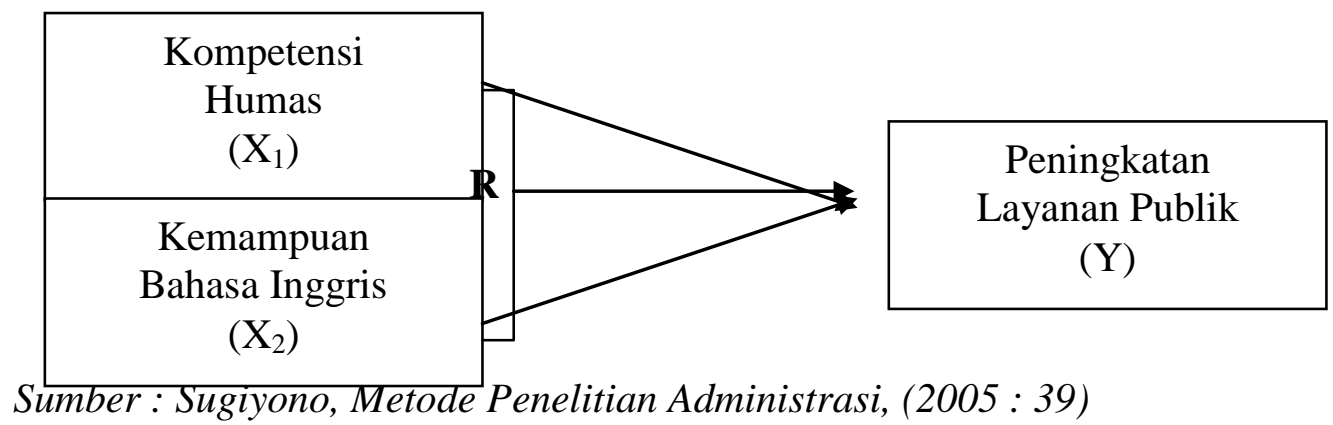

\section{HASIL DAN PEMBAHASAN}

I.a. Kabid humas DKI terbagi dalam 3 bagian, yaitu :1. bagian analisa dan monitoring berita 2 . bagian publikasi pewartaan dan 3 bagian kehumasan dan media

I.b. Tugas dan jenis kegiatan public relation officer pemda DKI khusus dalam membangun komunikasi khususnya komunikasi dalam berbahasa inggris disampaikan dan dibina kepada pihak media asing dalam hal ini pihak pers. Hal ini ditujukan untuk menyabarluaskan tentang hal yang positip yang dapat dan telah dikerjakan oleh pemda DKI Jakarta dalam memberikan pelayanan kepada masyarakat dan juga tamu Negara.

I.c. Pihak media atau pers yang sering bekerja sama dalam mempublikasikan atau media yang seriang datang dalam menggali informasi tentang apa ynag 
dilakukan oleh pemda DKI adalah : Strait Times, Alzazera, Jurnal dan BBC London.

I.d. Publikasi berita baik dalam penuangan press release atau press conference diperuntukkan bagi media asing yang tersebuat di atas, karena humas pemda DKI beranggapan bahwa publikasi tentang Indonesia ke luar yang dilakukan oleh media asing sangat perlu. Namun setelah publikasi dilaksanakan, humas pemda DKI dalam hal ini bagian analisa dan monitoring media massa kan melakukan pemeriksaaan dan analisa yang telah dilansir olah media asing tsb, untuk memeriksa apakah berita yang dimuat telah sesuai dengan yang sebenarnya dan semestinya.

III.a. Kemampuan bahasa Inggris kabid humas pemda DKI Jakarta yang terdiri dari 3 sub bidang, yaitu: bidang analisa dan monitoring berita, bagian publikasi dan warta, serta bagian kehumasan dan media massa dapat berkomunikasi dalam bahasa baik dalam bahasa lisan dan tulisan

III.b. Kemampuan bahasa inggris dalam bahasa tulisan masih dibawah standard dain masih perlu improvisasi, khusussnat pada aspek penguasaan bahasa inggris "dealing with visitor, giving clarification serta understanding customer" hal ini sangat perlu, sebab dari hasil interview yang dilakukan oleh tim peneliti, bahwa penguasaan aspek grammar dan struktur masih lemah. Kemampuan ini juga harus disertai oleh body language atau facial expression yang mengindikasikan bahwa kita siap melayani dan sadar akan pentingnya pelayanan public.

III.c. Kemampuan bahasa ingris tulisan bidang humas pemda DKI Jakarta telah berjalan dengan baik dan benar, mereka memiliki kemampuan dal.am menulis bahasa inggris. Hal ini terlihat dari beberapa contoh konsep pidato yang dibuat pada perayaan event-event tertentu. Bebearapa contoh pidata yang ditulis oleh bidang humas dapat dilihat pada lampiran

III.d. Pidato yang dikonsep dan dipublikasikan pada acara-acara atau event penting telah sesuai dengan struktur sebuah pidato (speech) dari outline sebuah pidato. Ketrampilan menulis ini dapat dilihat tidak hanya dari penunagan sebuah outline pidato, tetapi juga dari kemampuan menulis press release yang tim kami lampirkan dalam lampirkan.

III.e. Kompetensi personil bidang humas pemda DKI Jakarta telah memenuhi standard minimal yaitu:

Beberapa aspek yang terkandung dalam kompetensi adalah:

- Pengetahuan (knowledge) yaitu kesadaran dalam bidang kognitif dan mengetahui cara melakukan tugasnya.

- Pemahaman (understanding), yaitu memahami tentang apa yang dilayani.

- Kemampuan (skill), yaitu sesuatu yang dimiliki (keterampilan) apa yang dimiliki seorang PR untuk melakukan tugasnya.

- Nilai (value), yaitu standard perilaku yang telah diyakini atau telah menyatu dalam dirinya, misaalnya: standard perilaku seorang petugas Humas adalah: well informed dan bersifat terbuka 
- Minat (interest), yaitu kecenderungan seseorang untuk melakukan sesuatu pekerjaan.

Pengetahuan atau knowledge terlihat dari cara dan sikap menerima tamu, atau dealing with visitor serta keramahtamahan mereka dalam mencari data yang diperlukan orang atau publik yang datang untuk mencari dan mendapatkan informasi. Kecekatan personil di bidang ini begitu kooperatif dalam mencari data yang dibutuhkan dan memberikan langsung kepada pihak yang membutuhkan.

Understanding mereka sudah cukup terlihat bagaimana dia memahami kebutuhan tamu yang datang serta hal ini juga terlihat dari cara dan sikap menunjukkan arah dan atau giving direction.

Speaking test dalam penelitian ini dilakukan dengan menguji hal-hal sbb

Dealing with visitor

Giving reason

Expression opinion

Giving presentation

Product knowledge

Kemampuan atau skill yang dimiliki oleh kabid humas yang terdiri dari kasubag telah berjalan denegn baik, yaitu dengan menunjukkan kompetensi kemampuan atau unjuk kerja dalam menjalankan tugasnya sebagai public relation officer. Hal ini terlihat dari kemampuan mereka dalam menulis press release, dan menuangkan berita dengan menggunaka konsep piramida terbalik dengan tidaka melupakan unsure $5 \mathrm{~W} \mathrm{IH}$, contoh artikal yang ditulis mereka dapat dilihat pada lampiran

Nilai atau value, yaitu standard perilaku seorang public relation officer humas pemda DKI, telah memenuhi standard perilaku sikap seorang yang semestinya.. hal ini terlihat dari sikap dan perilaku dalam menerima tamu, dan para pengunjung ataupun rekan pers yang datang berkujung dalam mencari informasi.

Minat atau interest, yaitu kecenderungan seseorang untuk melakukan tugas sesuai dengan minat dan bidang dimana dia beekerja. Minat atau interest para staf public relation officer pada bidang humas pemda DKI ini telah berjalan secara optimal, dimana hal ini terlihat dari minat dan kreativitas dalam melaksanakan tugas-tugas kreatifnya, seperti mengumpulkan klipping sebagai bentuk monitoring terhadap perkembangan berita yang dimuat. Klipping tersebut akan diteliti kebenarannya serta diklarifikasi kebenarannya,. Hasil ini akan ditindaklanjuti dengan menghubungi dinas tekait yang termuat dalam berita tsb dan seterusnya akan dilakukan dan ditindaklanjuti untuk perbaikan.

Sementara, writing test dilakukan terhadap pemahaman menulis konsep surat dalam bahasa inggris, yaitu lay out 1, lay out 2 dan lay out 3.. Dari hasil penegmatan ini, mereka juga telah mampu menulis konsep surat dengen menggunakan struktur lay out 1,2 dan 3. kemampuan menulis surat ini juga terlihat dari konsep surat yang ditulis dalam bahasa Indonesia 
IV.a Masalah-masalah yang dihadapi oleh staf public relation pemda DKI dalam publikasi berita adalah : terdapatnya barita yang tidak sesuai dengan data yang sesungguhnya.

IV.b berita-berita yang dimuat dalam publikasi media asing seringkali tidak sesuai dengan data yang mutakhir, atau bahkan tidak di cross cek dengan data yang sebenarnya.

IV.c Masalah lain yang dirasakan dan dihadapi oleh public relation humas pemda DKI, ialah berita yang dimuat oleh media asing sering seringkali hanya memuat kondisi buruk yang semuanya bersifat satu arah. Hal yang diharapkan oleh mereka adalah hendaknya seimbang dan memuat juga berita yang mencantumkan hal- hal positif yang juga telah dilakukan olah pemda DKI sebagai bentuk upaya preventif atau persuasive dalam menangani kasus atau hal yang terjadi. Sehangga berita yang dimuat oleh pera atau media asing akan seimbang, karena tidak memuat ketidakbaikan tetapi hendaknya memuat upaya juga yang dilakukan olah pemda DKI.

IV.d Masalah yang paling urgent yang mereka hadapi adalah adanya kebutuhan untuk meningkatkan pengetahuan berbahasa inggris khususnya bahasa lisan atau kemampuan berbahasa inggris berkomunikasi dengan pers dalam memberikan penjelasan atau klarifikasi. Karena menurut pengakuan pihak humas bahwa sebenarnya ada ketidakpuasan yang dirasakan oleh mereka, karena sebenarnya selama ini mereka terbantu dalam hal memberikan penjelasan pada pihak pers dalam bentuk press conference atau press release. Pihak humas pemda DKI merasa terbantu sebab pihak media asing yang datang untuk mencari informasi dapat berkomunikasi dalam bahasa Indonesia. Press release dan pers conference dilaksanakan oleh humas pemda DKI di ruang pers dua kali dalam seminggu, dan pihak pers harus menyesuaikan dengan jadwal gubernur.

\section{KESIMPULAN}

Dari hasil pembahasan pada bab sebelumnya, maka dapat ditarik kesimpulan sbb:

1. humas pemda DKI telah mampu berkomunikasi dalam bahasa inggris. Kemampuan bahasa inggris ini ditunjukkan dari kemampuan menulis press release yang bersifat piramida terbalik dan pemuatan unsur $5 \mathrm{~W}$ IH.

2. kemampuan ini tercipta berkat bantuan dari pihak translater tersumpah yang eksis di bagian humas yang bersifat membantu dalam membina penulisan bahasa inggris.

3. kemudahan yang dirasakan oleh pihak humas DKI dalam memberikan layanan publik khususnya, public external dan media asing tidak menemukan kendala, karena kehadiran media asing atau pers asing telah mampu berbahasa Indonesia dengan baik, sehingga tidak menyulitkan bagi pihak humas untuk menyampaikan informasi.dan memberikan klarifikasi

4. pihak humas tidak memiliki dan merasakan kendala yang berarti, yang mereka rasakan adalah mereka sangat membutuhkan peningkatan bahasa inggris lisan dalam bentuk ketrampilan conversation, karena selama ini hal yang mereka kuasai adalah hanya penulisan bahasa tulisan, seperti membuat press release dan konsep 
sebuah pidato. Hal ini mereka dapat lakukan berkat bantuan translater yang tersedia dan dipekerjakan di bidang humas pemda DKI Jakarta.

5. secara keseluruhan kompetensi dan kemampuan komunikasi himas pemda DKI dalam menberikan pelayanan kepada publik khususnys publik external atau pihak pers asing telah beerjalan dengan baik dan sesuai dengan indikator standard kompetensi professi humas.

6. Unsur kompetensi professi humas yang mencakup : pengetahuan, ketrampilan, minat, nilai-nilai yang terkandung dalam tugas tsb dan pemahaman atau understanding telah tercakup semua dan telah dijalankan oleh humas pemda DKI beserta staf pembantu yang terlibat di humas tsb

7. humas pemda DKI Jakarta telah memiliki standard kompetensi dan kemampuan bahasa inggris dalam menjalankan tugas pokok dan fungsinya sebagai pusat informasi bagi masyarakat yang membutuhkan informasi. Informasi yang dimaksud disini adalah memberikan informasi kepada pihak media asing atau pers asing yang akan memuat tentang masalah dan program kerja pemda DKI Jakarta.

\section{DAFTAR PUSTAKA}

, 2003. Menteri Pendayagunaan Aparatur Negara dalam Surat Keputusan No.63/Kep/M.Pan/2003 tentang pedoman umum penyelenggaraan pelayanan publik.

2005. Buku program kerja setda DKI,

Gordon. 2003. Kompetensi. Konsep, Karakteristik dan Implementasi. Jakarta Grasindo

L. Cartside. 1981. Model Business Letters. Third edition, Jakarta. Bina Rupa Aksara

Maulana Yayan. 1999. English for Public Speakin. Practical Guide. Visi Pro Kessaint Blanc. Jakarta

Payaman J. Simanjuntak. 2005. Kompetensi. Jakarta. Gramedia

Rudol Doche f. 1993. “Public Relation” Teknik dan Taktik Presentasi, Jakarat. PT Golden Terayon Press

Weinstein Bob. 1992. "Public Relation” Meraih Sukses Lewat Karir Public Relation \& Customer Services. Semarang. Pahara Price

Yuliana, Yulia Eka Rini. 2002. Introduction to Communicate. Jakarta. Grasindo 